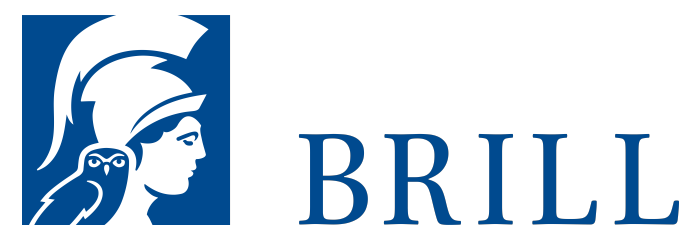

\title{
China and International Fisheries Law and Policy
}

\section{Author: Guifang Xue}

This book deals with China's response to international fisheries law and policy as envisaged in the LOSC framework and postLOSC fisheries instruments. A substantial effort was made to examine the major areas of China's national action on legislative harmonisation and policy adjustment to implement these instruments. China's regional fisheries cooperation, in the form of bilateral agreements with Japan, South Korea and Vietnam, is evaluated to identify the progress already achieved and the problems that remain to be solved in managing the shared fish stocks between these maritime neighbours. As the first monograph of its kind dealing with the complex issue of the global fisheries crisis and China's fisheries management practice over a significant period of time, the book builds a bridge between China and the world for a better understanding of Chinese fisheries management. It will be of great value to academics, professionals, and policy-makers alike.

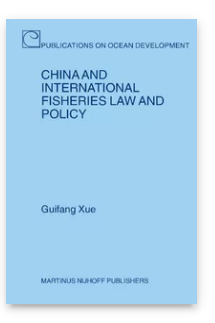

Pages: $x x i i, 3^{26}$

pp.

Language:

English

Subjects: Law of the Sea,

International

Law

Publisher: Brill | Nijhoff

Series:

Publications on

Ocean

Development,

Volume: 50

E-Book (PDF)

Released online:

o1 Dec 2005

ISBN: 978-90-

47-41619-7

List price

USD \$204.00

Hardback

Publication date:

28 Oct 2005

ISBN: 978-90-

04-14814-7

List price

USD \$204.00 
For more information see brill.com

Order information: Order online at brill.com +44330 333 0049 | customerservices@brill.com Submission information: brill.com/authors

Titles published by Brill | Fink, Brill | mentis or Brill | Schöningh: +49(o)715413279216| brill@brocom.de 